\section{Irrigation Frequency and Fertilizer Type Influence Necrotic Ring Spot of Kentucky Bluegrass}

\author{
B.P. Melvin ${ }^{1}$ and J.M. Vargas, Jr. ${ }^{2}$ \\ Michigan State University, 102 Pesticide Research Center, East Lansing, \\ MI 48824
}

Additional index words. moisture, fertilizer, stress, Poa pratensis, turfgrass

\begin{abstract}
Organic and synthetic fertilizers were evaluated under three irrigation regimes (daily, twice weekly, and rain only) for management of necrotic ring spot (Leptosphaeria korrae Walker \& Smith) of Kentucky bluegrass (Poa pratensis L.). Disease severity varied due to fertilizer and irrigation treatments. After 2 years of treatments, daily irrigation reduced disease incidence as compared to twice-weekly irrigation, while organic fertilizer, as a feathermeal-bonemeal-soybeanmeal mixture, when applied monthly at $48.8 \mathrm{~kg} \mathrm{~N} / \mathrm{ha}$, reduced disease incidence as compared to urea fertilizer. For 2 of 3 years, differences in disease incidence were attributable to irrigation treatments, and after 4 years, all $\mathbf{N}$ fertilizers reduced disease incidence as compared to no fertilizer.
\end{abstract}

Necrotic ring spot (NRS), incited by Leptosphaeria korrae, causes severe damage to bluegrasses (Poa spp.) in the temperate United States. NRS and summer patch, incited by Magnaporthe poae Landschoot \& Jackson, were previously known as fusarium blight (Couch and Bedford, 1966). NRS symptoms first appear as small (5 to $10 \mathrm{~cm}$ ), circular, ring-like patches of straw-colored turf in late spring, late summer to early fall, or both. As infection proceeds outward, grass in the center of the ring becomes necrotic and depressed, and invasion by less susceptible grasses or weeds occurs.

Leptosphaeria korrae grows and spreads in soil and thatch and apparently can infect host tissue up to several months in advance of symptom development (Smiley and Fowler, 1985). Infection causes extensive damage to the root system, causing reduced water absorption and nutrient uptake (Smiley and Fowler, 1985). Even though the pathogen may be inactive, infected plants are weakened and become more susceptible to disease during hot, dry periods (Vargas, 1986). Apparently, rapid fungus infection coupled with reduced plant vigor during periods of high temperature and moisture stress increase disease severity.

Cultural practices may alleviate stress to the host; however, the environmental conditions associated with fusarium blight, and later with NRS, have been perplexing. Water deficit (Fulton et al., 1974) and excess water and frequent irrigation have been associated with increased disease severity (Chastagner, 1985;

Received for publication 14 Mar. 1994. Accepted for publication 4 Apr. 1994. The cost of publishing this paper was defrayed in part by the payment of page charges. Under postal regulations, this paper therefore must be hereby marked advertisement solely to indicate this fact.

${ }^{1}$ Research Assistant, Dept. of Botany and Plant Pathology and the Pesticide Research Center.

${ }^{2}$ Professor, Dept. of Botany and Plant Pathology and the Pesticide Research Center.
Smiley, 1980). Sanders and Cole (1981) stated that drought or excess moisture stress appears to predispose bluegrasses to NRS disease development. Smiley (1980) also noted that severe disease outbreaks occur after periods of increased moisture or intermittent periods of wetness and drought.

Fertility practices may also have an effect on disease incidence. Turgeon and Meyer (1974) associated high $\mathrm{N}$ rates (293 to 390 $\mathrm{kg} \cdot \mathrm{ha}^{-1} \cdot \mathrm{year}^{-1}$ ) with an increase in severity of fusarium blight. Excess $\mathrm{N}$ fertilization has also been suggested as a predisposing factor to fusarium blight by other authors (Smiley, 1977; Turgeon, 1976; Vargas, 1981). Smiley (1983) noted that adequate fertility balance appears to be necessary for recuperation of diseased areas.

Since NRS and summer patch were previously known as fusarium blight, separate reevaluation of the effect of irrigation and fertility on each disease was required before cultural management practices could be implemented. Selected natural fertilizers have been shown to decrease disease severity (Huber and Watson, 1974), while irrigation practices can be manipulated to reduce moisture and heat stress. Midday irrigation (syringing) is often recommended to reduce drought stress and to provide a cooling effect (Beard, 1973; Turgeon, 1976; Vargas, 1981). We hypothesize that frequent application of organic fertilizers, combined with daily syringing, increases plant vigor and reduces NRS symptom expression.

The objective of this study was to evaluate six organic and synthetic fertilizer treatments under three irrigation regimes for NRS disease management.

\section{Materials and Methods}

Five fertilizers available commercially and a biostimulant were examined in field experiments. Organic fertilizers containing viable microorganisms were provided by Ringer Corp. (Minneapolis) and Sustane Corp. (Can- non Falls, Minn.) and are labeled Lawn Restore and Sustane, respectively. Lawn Restore has a macronutrient analysis of $9 \mathrm{~N}-4 \mathrm{P}-4 \mathrm{~K}$ and consists of various organic and inorganic constituents, including feathermeal, soybeanmeal, and bonemeal. Sustane is aerobically composted turkey manure with a macronutrient analysis of $5 \mathrm{~N}-2 \mathrm{P}-4 \mathrm{~K}$. A synthetic slow-release $\mathrm{N}$ source Nitroform (Nitroform Corp.,Wilmington, Del.) was also examined to determine if slow-release $\mathrm{N}$ alone affects disease severity. Nitroform is composed of low-molecular-weight methyleneurea polymers with an analysis of $38 \mathrm{~N}-0 \mathrm{P}-0 \mathrm{~K}$. The biostimulant product, Bio Grounds Keeper (BGK), was provided by Bio Grounds Keeper, (formerly KLMBio Systems) of Bloomington, Minn. BGK is a biologically active product with $>10^{6}$ colony-forming units $/ \mathrm{ml}$ in a $10 \%$ humic acid solution, and a macronutrient analysis of $0 \mathrm{~N}-0 \mathrm{P}-2 \mathrm{~K}$. Since this product alone cannot provide enough $\mathrm{N}$ for sustained plant growth, a synthetic slow-release $\mathrm{N}$ fertilizer (NITRO-26 CRN; Growth Products Corp., White Plains, N.Y.) was also applied to plots treated with BGK. NITRO-26 CRN has a $26 \mathrm{~N}-0 \mathrm{P}-0 \mathrm{~K}$ analysis with a total of $20.8 \%$ methylene diurea and $5.2 \%$ urea. The inorganic fertilizer control consisted of urea, phosphoric acid as treble superphosphate, and potash as potassium chloride, blended to provide a macronutrient analysis of $9 \mathrm{~N}-4 \mathrm{P}-4 \mathrm{~K}$.

Treatments were applied to a mixture of 'Baron', 'Bristol', and 'Victa' Kentucky bluegrass at the Hancock Turfgrass Research Center, Michigan State Univ., East Lansing. The stand was composed of muck sod laid over a sandy loam soil with the following analysis: $60.4 \%$ sand, $22.7 \%$ silt, $16.9 \%$ clay, and $\left(\mathrm{kg} \cdot \mathrm{ha}^{-1}\right) 75 \mathrm{P}, 132 \mathrm{~K}, 1971 \mathrm{Ca}, 394 \mathrm{Mg}$; pH was 7.5 and cation exchange capacity was 60 $\mathrm{mmol} \cdot \mathrm{kg}^{-1}$. The turf stand was established in Oct. 1985 and maintained at a height of 61 mm. In Nov. 1985 and May 1986, the test area was infested with wheat seed colonized by $L$. korrae (Otto, 1987). In May 1988, when this study was initiated, symptoms typical of NRS (i.e., ring-like patches of straw-colored turf along with necrotic and depressed areas) were visible throughout the test area.

Factorial treatments were three irrigation and six fertilizer treatments. Irrigation treatments were applied to randomly selected 12.2 $\times 12.2-\mathrm{m}$ main plots with three replications. Fertilizer treatments were applied to $1.8 \times 1.8$ $\mathrm{m}$ split plots within each irrigation main plot with alleyways between plots. Irrigation treatments were 1) daily, $2.5 \mathrm{~mm} \cdot \mathrm{day}^{-1}$ supplemental irrigation applied at $1200 \mathrm{HR}$; 2) twice weekly, based on $80 \%$ of open-pan evaporation, applied on Monday and Thursday at night; and 3) rain only. Irrigation treatments began in May and ended in either late October or early November each year from 1986 through 1990. A drought occurred in June and July 1988, thus irrigation rates of the daily irrigation regime were increased to $5.0 \mathrm{~mm} \cdot$ day $^{-1}$ $(2.5 \mathrm{~mm}$ at $1200 \mathrm{HR}$ and at $1500 \mathrm{HR})$ to reduce moisture stress and prevent wilt.

Fertilizer treatments were applied at 48.8 $\mathrm{kg} \mathrm{N} / \mathrm{ha}$ and BGK at the label rate of 19.1 
liters $\cdot h a^{-1}$. Treatments were applied monthly beginning in May and ending in October (six applications) of each year (1987-90). Granular treatments were preweighed and applied by hand. Liquid treatments were applied as a drench with 7.5 liters water. Irrigation and fertilizer treatments were applied to the same test plots each year.

Plots were monitored for NRS expression from 1987 to 1990. Data were taken at peak symptom expression of each year by counting the number of ring spots in each plot. Data were tested using analysis of variance; the LSD test $(P \leq 0.05)$ was used to test for significance of differences between treatment means. To determine seasonal effects of irrigation treatments on soil and thatch moisture levels, three core samples, each $50 \mathrm{~mm}$ in diameter, including soil and thatch, were removed from each irrigation block. Ten grams of soil and thatch were removed from each core, and moisture was measured gravimetrically.

\section{Results and Discussion}

In 1988, from late May to early August, lack of rainfall resulted in drought conditions causing low moisture levels (Table 1) and severe wilting of the rain-only plots. Heavy rainfall during mid-August and late September resulted in an increase in moisture levels. Although irrigation rates were raised from 2.5 to $5.0 \mathrm{~mm} \cdot \mathrm{day}^{-1}$ for the daily irrigation during June and July 1988 to reduce wilting, more water was applied to turf blocks maintained under twice-weekly irrigation (Table 2). Soil moisture levels were nearly equal for daily and twice-weekly irrigation (Table 1). However, plots receiving daily irrigation had generally higher and more consistent thatch moisture concentrations than plots receiving twiceweekly irrigation (Table 1). During the weather

Table 1. Effect of irrigation treatments on soil and thatch moisture concentration in Kentucky bluegrass muck sod.

\begin{tabular}{|c|c|c|c|c|c|c|}
\hline \multirow[b]{4}{*}{ Date } & \multicolumn{6}{|c|}{ Percent moisture (by wt) } \\
\hline & \multicolumn{3}{|c|}{ Soil } & \multicolumn{3}{|c|}{ Thatch } \\
\hline & \multicolumn{6}{|c|}{ Frequency of application } \\
\hline & Daily & $\begin{array}{c}\text { Twice } \\
\text { weekly }\end{array}$ & $\begin{array}{l}\text { Rain } \\
\text { only }\end{array}$ & Daily & $\begin{array}{c}\text { Twice } \\
\text { weekly }\end{array}$ & $\begin{array}{l}\text { Rain } \\
\text { only }\end{array}$ \\
\hline \multicolumn{7}{|c|}{1988} \\
\hline 23 June & 10.2 & 16.8 & 4.3 & 49.8 & 31.2 & 19.3 \\
\hline 8 July & 15.3 & 17.5 & 3.9 & 30.8 & 28.4 & 13.2 \\
\hline 19 July & 22.3 & 19.4 & 15.3 & 37.3 & 41.2 & 34.7 \\
\hline 29 July & 21.0 & 14.3 & 7.6 & 35.4 & 18.7 & 15.5 \\
\hline 9 Aug. & 23.4 & 17.4 & 10.2 & 43.2 & 25.4 & 25.6 \\
\hline 25 Aug. & 19.9 & 19.5 & 19.5 & 35.9 & 27.9 & 35.0 \\
\hline 15 Sept. & 24.7 & 21.5 & 16.2 & 44.1 & 27.2 & 19.4 \\
\hline 3 Nov. & 30.1 & 30.1 & 17.1 & 42.0 & 28.3 & 39.5 \\
\hline \multicolumn{7}{|c|}{1989} \\
\hline 24 May & 21.1 & 20.0 & 19.3 & 33.3 & 29.9 & 36.7 \\
\hline 28 June & 22.1 & 23.4 & 21.9 & 38.3 & 36.3 & 39.2 \\
\hline 8 July & 22.3 & 18.2 & 14.6 & 45.7 & 39.7 & 37.2 \\
\hline 26 July & 23.6 & 22.3 & 14.4 & 40.2 & 37.2 & 33.8 \\
\hline 2 Aug. & 21.3 & 19.9 & 12.3 & 32.7 & 26.7 & 23.5 \\
\hline 18 Aug. & 22.1 & 19.6 & 17.9 & 31.9 & 22.6 & 23.0 \\
\hline 29 Aug. & 20.6 & 16.7 & 14.0 & 39.6 & 44.2 & 35.1 \\
\hline 15 Sept. & 23.2 & 21.0 & 20.5 & 39.3 & 34.2 & 36.8 \\
\hline 27 Sept. & 24.0 & 20.6 & 17.9 & 42.1 & 24.7 & 30.3 \\
\hline 30 Oct. & 22.9 & 20.7 & 15.9 & 36.9 & 27.7 & 25.5 \\
\hline
\end{tabular}

Table 2. Amount of water applied (mm) per irrigation and rain (1988 and 1989).

was required to maintain soil and thatch mois ture levels if applied daily rather than twice weekly (Table 2). As expected, moisture levels in the soil and thatch of the rain-only turf blocks were generally the lowest (Table 1).

NRS severity on 28 Sept. 1988 was less for daily than for twice-weekly irrigation (Tables 3 and 4). Due to drought, rain-only plots were severely wilted and were not rated. Plots fertilized with Lawn Restore and Sustane had less severe NRS than those given inorganic fertilizer, Nitroform, or no fertilizer (Tables 3 and 4).

Rainfall was more regular in 1989 than in 1988 , so differences in water application rates between the daily and twice-weekly irrigation treatments were small (Table 2). However, infrequent rainfall in early July prompted more water to be applied to test plots maintained under the twice-weekly treatment compared to daily irrigation. As with 1988, moisture levels of the soil and thatch in 1989 were generally higher and more consistent in test plots receiving daily irrigation in contrast to plots maintained under twice-weekly or rainonly watering (Table 1 ).

Disease ratings in 1989 again revealed significant differences $(\mathrm{F}=5.73)$ in NRS incidence between irrigation treatments (Table 3 ). The NRS severity with daily irrigation was less than with rain only (Table 4). Lawn Restore-fertilized plots had less severe NRS than plots treated with inorganic fertilizer, Nitroform, or not fertilized (Tables 3 and 4).

Disease ratings taken in 1990 showed no differences in disease incidence between irrigation treatments. All fertilized plots had less severe NRS than nonfertilized plots (Tables 3 and 4).

Disease ratings taken at peak symptom expression each year indicated significant difronmental factors in the field. Agron. J. 58:337339.

Beard, J.B. 1973. Turfgrass: Science and culture. Prentice Hall, Englewood Cliffs, N.J.

Chastagner, G.A. 1985. Symptoms of necrotic ring spot. Grounds Maintenance May, p. 52.

Couch, H.B. and E.R. Bedford. 1966. Fusarium blight of turfgrasses. Phytopathology 56:781786.

Duff, D.T. and J.B. Beard. 1966. Effects of air movement and syringing on the micro-climate of bentgrass turf. Agron. J. 58:495-497.

Fulton, D.E., H. Cole, Jr., and P.E. Nelson. 1974. Fusarium blight symptoms on seedling and mature Merion Kentucky bluegrass plants inoculated with Fusarium roseum and Fusarium tricinctum. Phytopathology 64:354-357.

Garrett, S.D. 1956. Biology of root-infecting fungi. Cambridge Univ. Press, London.

Huber, D.M. and R.D. Watson. 1974. Nitrogen form and plant disease. Annu. Rev. Phytopathology 12:139-165.

Otto, M.E. 1987. Studies in the isolation, pathogenicity, epidemiology and control of Leptosphaeria korrae causing necrotic ring spot of Poa pratensis L. in Michigan. MS Thesis, Michigan State Univ., East Lansing.

Sale, P.J.M. 1965. Changes in water and soil temperature during overhead irrigation. Weather 20:242-245. 
Table 3. Effects of fertilizer and irrigation treatments on necrotic ring spot severity of Kentucky bluegrass test plots, analysis of variance summary.

\begin{tabular}{|c|c|c|c|c|c|c|c|}
\hline \multirow[b]{3}{*}{$\begin{array}{l}\text { Source of } \\
\text { variation }\end{array}$} & \multirow[b]{3}{*}{$\mathrm{df}$} & \multicolumn{6}{|c|}{ Date of examination } \\
\hline & & \multicolumn{2}{|c|}{28 Sept. 1988} & \multicolumn{2}{|c|}{28 Sept. 1989} & \multicolumn{2}{|c|}{10 Nov. 1990} \\
\hline & & $\begin{array}{l}\text { Mean } \\
\text { square }\end{array}$ & $\begin{array}{c}\mathrm{F} \\
\text { value }\end{array}$ & $\begin{array}{l}\text { Mean } \\
\text { square }\end{array}$ & $\begin{array}{c}\mathrm{F} \\
\text { value }\end{array}$ & $\begin{array}{l}\text { Mean } \\
\text { square }\end{array}$ & $\begin{array}{c}\mathrm{F} \\
\text { value }\end{array}$ \\
\hline$\overline{\text { Irrigation }(\mathrm{I})}$ & 2 & 58.778 & $10.96^{*}$ & 3.130 & $5.73^{*}$ & 3.130 & $3.07^{\mathrm{Ns}}$ \\
\hline Error (a) & 6 & 5.361 & & 0.546 & & 1.019 & \\
\hline Fertilizer $(F)$ & 5 & 11.311 & $9.47^{* *}$ & 7.974 & $28.33^{* *}$ & 19.719 & $19.94^{* *}$ \\
\hline $\mathrm{I} \times \mathrm{F}$ & 10 & 1.044 & $0.87^{\text {Ns }}$ & 0.485 & $1.72^{\mathrm{Ns}}$ & 1.641 & $1.66^{\mathrm{Ns}}$ \\
\hline Error (b) & 35 & 1.194 & & 0.281 & & 0.989 & \\
\hline
\end{tabular}

Ns, *,**Nonsignificant or significant at $P \leq 0.05$ or 0.01 , respectively.

Table 4. Necrotic ring spot severity in response to six fertilizer and three irrigation treatments applied to Kentucky bluegrass (1988-90).

\begin{tabular}{lccc}
\hline \hline & \multicolumn{3}{c}{ Avg no. rings/plot } \\
\cline { 2 - 4 } Variable & 28 Sept. 1988 & 28 Sept. 1989 & 10 Nov. 1990 \\
\hline Irrigation treatment & $1.4 \mathrm{a}^{\mathrm{z}}$ & $0.6 \mathrm{a}$ & 1.4 \\
$\quad$ Daily & $4.0 \mathrm{~b}$ & $1.0 \mathrm{ab}$ & 1.8 \\
$\quad$ Twice weekly & $--\mathrm{y}$ & $1.4 \mathrm{~b}$ & 0.9 \\
$\quad$ Rain only & $0.8 \mathrm{a}$ & $0.1 \mathrm{a}$ & $0.4 \mathrm{a}$ \\
Fertilization treatment & $1.5 \mathrm{ab}$ & $0.4 \mathrm{ab}$ & $0.6 \mathrm{a}$ \\
$\quad$ Lawn Restore 9-4-4 & & & \\
Sustane 5-2-4 & $2.8 \mathrm{bc}$ & $0.5 \mathrm{ab}$ & $0.7 \mathrm{a}$ \\
Bio Grounds Keeper & $3.2 \mathrm{c}$ & $0.7 \mathrm{~b}$ & $1.0 \mathrm{a}$ \\
$\quad$ + Nitro 26 CRN 26-0-0 & $3.4 \mathrm{~cd}$ & $1.8 \mathrm{c}$ & $1.2 \mathrm{a}$ \\
Inorganic 9-4-4 & $4.7 \mathrm{~d}$ & $2.6 \mathrm{~d}$ & $4.3 \mathrm{~b}$ \\
$\quad$ Nitroform 38-0-0 & &
\end{tabular}

${ }^{2}$ Mean separation within treatments and columns by LSD, $P \leq 0.05$.

${ }^{y}$ No rating due to drought.

${ }^{x}$ Fertilization was monthly at $48.8 \mathrm{~kg} \mathrm{~N} / \mathrm{ha}$ from May through October of each year (Bio Grounds Keeper was applied at 19.1 liters $\mathrm{ha}^{-1}$ ).
Sanders, P.L. and H. Cole, Jr. 1981. The fusarium diseases of turfgrass, p. 195-209. In: P.E. Nelson, T.A. Toussoun, and R.J. Cook (eds.). Fusarium: Diseases, biology and taxonomy. Pennsylvania State Univ. Press, University Park.

Smiley, R.W. 1977. Reflections on fusarium blight. Weeds Trees \& Turf 16(5):22-28.

Smiley, R.W. 1980. Fusarium blight of Kentucky bluegrass: New perspectives, p. 155-178. In: P.O. Larson and B.G. Joyner (eds.). Advances in turfgrass pathology. Harcourt, Brace, Jovanovitch, Duluth, Minn.

Smiley, R.W. 1983. Compendium of turfgrass diseases. Amer. Phytopathological Soc., St. Paul, Minn.

Smiley, R.W. and M.C. Fowler. 1984. Leptosphaeria korrae and Phialophora graminicola associated with fusarium blight syndrome of Poa pratensis in New York. Plant Dis. 68:440-442.

Smiley, R.W. and M.C. Fowler. 1985. Techniques for inducing summer patch symptoms on $\mathrm{Poa}$ pratensis. Plant Dis. 69:482.

Turgeon, A.J. 1976. Effects of cultural practices on fusarium blight incidence in Kentucky bluegrass. Weeds Trees \& Turf 15:38-40.

Turgeon, A.J. and W.A. Meyer. 1974. Effects of mowing height and fertilization levels on disease incidence in five Kentucky bluegrasses. Plant Dis. Rpt. 58:514-516.

Vargas, J.M. 1981. Management of turfgrass diseases. Burgess Publ. Co., Minneapolis.

Vargas, J.M. 1986. The patch diseases. Greenmaster 22:9-11. 